\title{
A Rare Cause of Acute Abdomen: Perforation of Duodenal Diverticulum Containing Ectopic Pancreatic Tissue
}

\author{
Yavuz Özdemir, Bülent Güleç, Illker Sücüllü, Ali illker Filiz \\ Department of General Surgery, Gülhane Military Medical Academy, Haydarpaşa Training Hospital, İstanbul, Turkey
}

\begin{abstract}
Perforation is a rare but serious complication of a duodenal diverticulum and often presents itself with nonspecific symptoms and signs. Ectopic pancreatic tissue within a duodenal diverticulum is another rare situation. In this article, we report a case of an 87 year-old woman who presented with spontaneous perforation of the duodenal diverticulum. Operative resection and simple closure of the duodenum was performed. Ectopic pancreatic tissue was observed within the diverticulum at histological evaluation.
\end{abstract}

Key Words: Duodenal diverticulum, perforation, acute abdomen, ectopic pancreatic tissue

Received: 24.08.2009

Accepted: 09.11.2009

\section{Introduction}

Duodenum is the second most common site of diverticula after the colon (1-3). The incidence of duodenal diverticulas is reported as 1 to $6 \%$ in upper gastrointestinal contrast studies, 12 to $27 \%$ in endoscopic studies and up to $22 \%$ in postmortem analysis $(4,5)$. The aetiology of duodenal diverticulas remains unknown. The classification of diverticulas can be made as intraluminal or extraluminal, true or false, and congenital or acquired. Diverticulas are mainly located along the pancreatic border of the duodenum, and approximately $60-75 \%$ of these are found within $2 \mathrm{~cm}$ of the ampulla of Vater $(6,7)$.

Duodenal diverticulas mostly remain asymptomatic. They can be diagnosed when a diverticula related complication develops. The possible complications include common bile duct obstruction, acute or chronic recurrent pancreatitis, partial duodenal obstruction, diverticulitis, ulceration, perforation, bleeding, enterolith formation and malignant degeneration.

Perforation, although rare, is the most serious complication of duodenal diverticulas. It has a mortality rate of up to $30 \%(2,3)$. Diverticula perforation can occur as a result of preceding diverticulitis, ulcerations, enterocolitis, blunt abdominal trauma or diagnostic procedures $(6,7)$. To the best of our knowledge, there is only one case with a perforated extraluminal diverticulum containing ectopic pancreatic tissue (8). Upper gastrointestinal endoscopy was the cause of perforation in that case (8). Here, we report a case with a spontaneously perforated extraluminal duodenal diverticulum which contained ectopic pancreatic tissue.

\section{Case Report}

An 87 year old lady was admitted to our emergency department complaining of severe epigastric pain that had been ongoing for 48 hours and was progressively worsening. On admission, the patient was tachycardic and subfebrile $\left(37.2^{\circ} \mathrm{C}\right)$. Her physical examination revealed right upper quadrant tenderness suggestive of peritonitis. Her white blood cell count was $29 \times 10^{3} / \mathrm{mcL}$, and she was in a septic status. Plain abdominal X-ray was normal. Subsequent abdominal ultrasonography showed diffuse intraabdominal anechoic free liquid. Emergent exploratory laparotomy was then performed. Intraoperative examination showed diffuse, fibro-purulent, bilious free liquid. Complete duodenal mobilization revealed a duodenal diverticulum originating from the posterolateral part of the second portion of the duodenum. The diverticulum was perforated from the apex. The diverticulum was dissected free and a $30 \mathrm{~mm}$ abdominal stapler was used to perform diverticulectomy (Figure 1). Histopathologic examination of the specimen demonstrated a duodenal diverticulum containing ectopic pancreatic tissue (Figure 2).

\section{Discussion}

Duodenal diverticula are not rare, but complications are uncommon and usually require surgical treatment. The frequency of duodenal diverticula increases with age and the overall estimated incidence is $5-22 \%$ in a healthy population $(6,9)$. Approximately $90 \%$ of duodenal diverticula are solitary. 


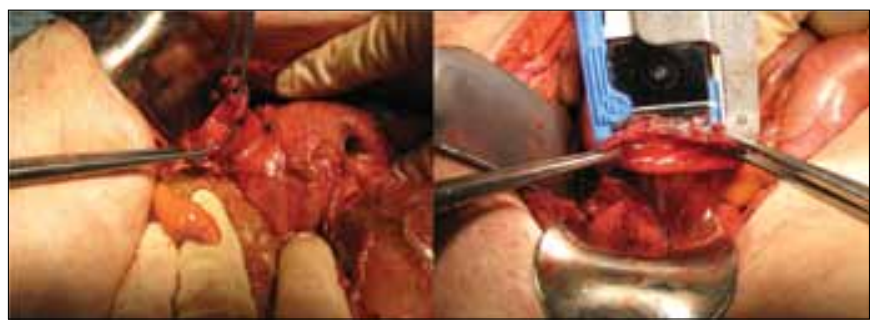

Figure 1. Intraoperative view of (a) perforated, (b) stapled duodenal diverticulum

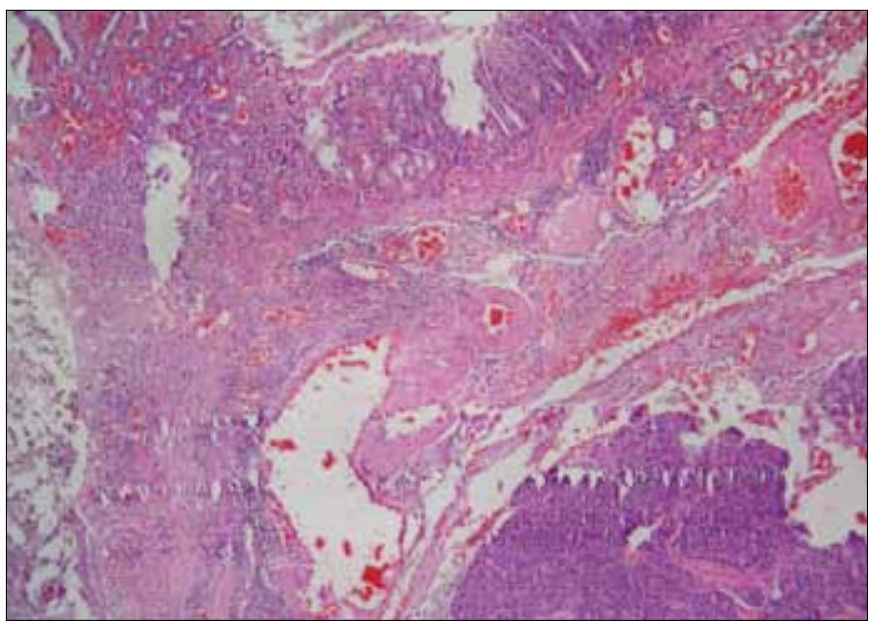

Figure 2. Histologic view of ectopic pancreatic tissue

Symptomatic diverticula are rare and usually occur in those over 60 years. Our patient was 87 years old and there was a solitary duodenal diverticulum at exploration.

Pancreatic tissue found outside the pancreas is called ectopic pancreatic tissue. The incidence in postmortem studies vary from 0.5 to $13.7 \%$, more commonly in males (10). The most common locations are the stomach, duodenum and jejunum (10). Also, it has been reported in association with duodenal diverticula $(11,12)$. This tissue may cause inflammation, bleeding, obstruction, perforation and malignant degeneration $(10,13)$.

There are many reported possible complications of duodenal diverticula. The most frequent complications are; inflammation, hemorrhage, pancreatitis, and common bile duct obstruction. Surgical treatment is required in only $1-2 \%$ of cases with complicated duodenal diverticula (14). The most serious and rare complication of duodenal diverticula is perforation, and it is frequently associated with significant mortality and morbidity $(15,16)$.

The diagnosis of complications associated with duodenal diverticula, especially perforation, has several difficulties. Almost half of the conventional radiological examinations show no abnormalities (17). If there is a clinical suspicion of a perforated duodenal diverticula, contrast enhanced $\mathrm{CT}$ is the most sensitive examination (18). When the literature is reviewed, it can be seen that only a small portion of duodenal perforation cases were diagnosed preoperatively $(6,19)$. Our patient was admitted to our emergency service 48 hours late. At the admission the signs of acute abdomen were established, and the patient was in septic status. Therefore further investigation was not considered and emergent exploratory laparotomy was performed.

Although surgical intervention is the most common approach, there are a few reports of conservative management with antibiotics and percutaneous drainage $(4,20,21)$. The treatment of choice is diverticulectomy with a simple duodenal closure and concomitant drainage $(2,6)$. When there is duodenal inflammation, a diversion such as gastrojejunostomy or tube duedonostomy should be performed. Laparoscopic approach is also possible, but the position of the diverticulum is important (1). Only mildly affected patients are likely to benefit from non-operative management, which consists of nasogastric decompression, percutaneous drainage and wide spectrum antibiotics. In our case, diverticulectomy was performed using a $30 \mathrm{~mm}$ intraabdominal stapler.

Treatment of duodenal diverticula has surgical complications such as bile duct injury, duodenal fistula formation, abscess formation, pancreatitis and sepsis (2). The overall surgical complication rate is reported to be $41 \%$, with a $20 \%$ rate of duodenal fistula formation and a $4 \%$ rate of intraabdominal abscess formation (6).

In conclusion, perforation is a rare but serious complication of duedonal diverticulas. Surgeons should keep in mind that diverticulas may perforate spontaneously and lead to acute abdomen. Spontaneous perforation may be a result of a complication of the ectopic pancreas. Successful management requires clinical awareness and early diagnosis.

\section{Conflict of Interest}

No conflict of interest was declared by the authors.

\section{References}

1. Graur F, Bala O, Bodea R, Geczi-Toth I, Vlad L, lancu C. Laparoscopic resection of duodenal diverticulum. A case report. Rom J Gastroenterol 2005;14:405-8.

2. Bergman S, Koumanis J, Stein LA, Barkun JS, Paraskevas S. Duodenal diverticulum with retroperitoneal perforation. Can J Surg 2005;48:332.

3. Yokomuro S, Uchida E, Arima Y, Mizuguchi Y, Shimizu T, Kawahigashi $Y$, et al. Simple closure of a perforated duodenal diverticulum: a case report. J Nihon Med Sch 2004;71:337-9. [CrossRef]

4. Marhin WW, Amson BJ. Management of perforated duodenal diverticulum. Can J Surg 2005;48:79-80.

5. Afridi SA, Fichtenbaum CJ, Taubin H. Review of duodenal diverticula. Am J Gastroenterol 1991;86:935-8.

6. Duarte B, Nagy KK, Cintron J Perforated duodenal diverticulum. Br J Surg 1992;79:877-81. [CrossRef]

7. Franzen D, Gurtler T, Metzger U. Solitary duodenal diverticulum with enterolith as a rare cause of acute abdomen. Swiss Surg 2002;8:277-9. (Article in German) [CrossRef]

8. Volchok J, Massimi T, Wilkins S, Curletti E. Duodenal diverticulum: case report of a perforated extraluminal diverticulum containing ectopic pancreatic tissue. Arch Surg 2009;144:188-90. [CrossRef]

9. Lida F. Transduodenal diverticulectomy for periampullar diverticula. World J Surg 1979;3:135-6. [CrossRef]

10. Christodoulidis G, Zacharoulis D, Barbanis S, Katsogridakis E, Hatzitheofilou K. Heterotopic pancreas in the stomach: a case report and literature review. World J Gastroenterol 2007;13:6098-100. [CrossRef] 
11. D'Alessio MJ, Rana A, Martin JA, Moser AJ. Surgical management of intraluminal duodenal diverticulum and coexisting anomalies. J Am Coll Surg 2005;201:143-8. [CrossRef]

12. Osnes M, Løotveit $T$, Larsen $S$, Aune S. Duodenal diverticula and their relationship to age, sex, and biliary calculi. Scand J Gastroenterol 1981;16:103-7.

13. Armstrong CP, Kinig PM, Dixon JM, Macleod IB. The clinical significance of heterotopic pancreas in the gastrointestinal tract. $\mathrm{Br}$ J Surg 1981;68:384-7. [CrossRef]

14. Condon RE. Disorders of the stomach and duodenum. In: Nyhus LM, Wastell C, editors. Surgery of the stomach and duodenum. 4th ed. Boston: Little Brown and Company; 1986. p. 573-625.

15. Psathakis D, Utschakowski A, Muller G, Broll R, Bruch HP. Clinical significance of duodenal diverticula. J Am Coll Surg 1994;178:257-60.

16. Andromanakos N, Filippou D, Skandalakis P, Kouraklis G, Kostakis $A$. An extended retroperitoneal abscess caused by duodenal diverticulum perforation: report of a case and short review of the literature. Am Surg 2007;73:85-8.

17. Papalambros E, Felekouras E, Sigala F, Kiriakopoulos A, Giannopoulos A, Aessopos A, et al. Retroperitoneal perforation of a duodenal diverticulum with colonic necrosis-report of a case. Zentralbl Chir 2005;130:270-3. [CrossRef]

18. Goodman P, Raval B, Zimmerman G. CT diagnosis of perforated duodenal diverticulum. Clin Imaging 1989;13:321-2. [CrossRef]

19. Juler GL, List JW, Stemmer EA, Connolly JE. Perforating duodenal diverticulitis. Arch Surg 1969;99:572-8.

20. Van Beers B, Trigaux JP, De Ronde T, Melange M. CT findings of perforated duodenal diverticulitis. J Comput Assist Tomogr 1989;13:528-30. [CrossRef]

21. Tsukamoto T, Ohta $Y$, Hamba H, Sasaki Y, Tokuhara T, Kubo S, et al. Perforated duodenal diverticulum: report of two cases. Hepatogastroenterology 1999;46:1755-8. 